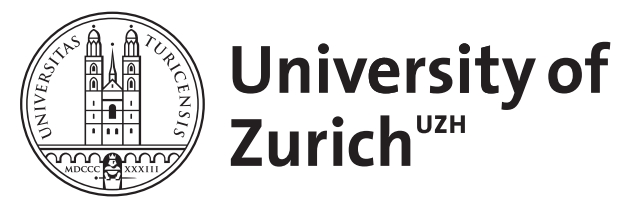

\title{
In vitro derivation of melanocytes from embryonic neural crest stem cells
}

\author{
Shakhova, Olga ; Sommer, Lukas
}

\begin{abstract}
During development, melanocyte progenitors originate from the neural crest, a transient embryonic structure in vertebrates that gives rise to a variety of cell types including neurons and glia of the peripheral nervous system, smooth muscle cells of the cardiovascular system, chondrocytes and osteoblasts of the craniofacial elements, and pigment cells in the skin. In this chapter, we describe a method for the differentiation of multipotent embryonic neural crest stem cells into differentiated pigmented melanocytes by using in vitro explant culture system. This protocol allows the dissection of genetic and cellular mechanisms regulating neural crest stem cell and melanocyte development. Based on this knowledge it is possible to make predictions about processes that might also be implicated in melanoma initiation and progression.
\end{abstract}

DOI: https://doi.org/10.1007/7651_2015_305

Posted at the Zurich Open Repository and Archive, University of Zurich ZORA URL: https://doi.org/10.5167/uzh-122977

Journal Article

Accepted Version

Originally published at:

Shakhova, Olga; Sommer, Lukas (2015). In vitro derivation of melanocytes from embryonic neural crest stem cells. Methods in Molecular Biology:1-8.

DOI: https://doi.org/10.1007/7651_2015_305 
Title

“In vitro derivation of melanocytes from embryonic neural crest stem cells"

Olga Shakhova* and Lukas Sommer

* Corresponding author

Institute of Anatomy, University of Zurich, Winterthurerstrasse 190, 8057 Zurich, Switzerland 


\begin{abstract}
In recent years, it has become apparent that the mechanisms by which cancer cells self-renew, migrate and invade, resemble their embryonic counterparts and that during the steps of the initiation and progression cancer cells can reprogram into embryonic-like cells $(1,2)$. Melanoma is one of the most aggressive human cancers and it is believed to originate from the genetic deregulation of the cells of the melanocytic lineage. As many other cancers, melanoma cells display the expression of developmental genes and can be reprogrammed when exposed to embryonic environment $(3,4)$. During development, melanocyte progenitors originate from the neural crest, a transient embryonic structure in vertebrates that gives rise to a variety of cell types including neurons and glia of the peripheral nervous system, smooth muscle cells of the cardiovascular system, chondrocytes and osteoblasts of the craniofacial elements, and pigment cells in the skin. In this chapter, we describe a method for the differentiation of embryonic neural crest stem cells into melanocytes. This protocol allows the dissection of genetic and cellular mechanisms regulating neural crest stem cell and melanocyte development. Based on this knowledge it is possible to make predictions about processes that might also be implicated in melanoma initiation and progression.
\end{abstract}

Key words: neural crest, stem cells, melanocyte differentiation

\title{
1. Introduction
}

Neural crest cells originate in the ectoderm at the margins of the neural tube and, after a phase of epithelial-mesenchymal transition and extensive migration, settle down in different parts of the body to contribute to the formation of a plethora of different tissues and cell types, including melanocytes (5). Knowledge of neural crest cell biology might help to understand the basic mechanisms underlying growth and metastasis of cancers originating from neural crest derivatives, such as melanoma. Indeed, melanoma-initiating cells have been reported to express the neural crest stem cell marker p75 (low affinity neurotrophin receptor) while lacking expression of markers of differentiated melanocytes, such as tyrosinase, melan-A and melanomaassociated antigen MAGE $(6,7)$. Moreover, the neural crest stem cell transcription factor Sox10 was recently shown to be expressed in mouse and human melanoma and to promote the formation and maintenance of melanoma (8). Taken together, these recent findings suggest that melanoma cells might utilize genetic and cellular programmes similar to embryonic neural crest stem cells.

After emigration from the neural tube in culture, neural crest stem cells can be isolated and expanded in vitro as a monolayer of substrate-attached multipotent cells $(9,10)$. Moreover, neural crest cells can be propagated in vitro at clonal density allowing the investigation of multipotency at the single cell level. Undifferentiated, multipotent neural crest stem cells are characterized by the 
expression of the low affinity neurotrophin receptor p75 transcription factor Sox10 (11). When grown in a rich medium containing serum or chicken embryo extract, these cells differentiate into a number of neural crest derivatives. Unlike for other neural crest-derived lineages, an instructive growth factor promoting the melanocytic lineage has not yet been identified. However, there are several factors known to promote the survival and proliferation of neural crest-derived melanocytic progenitors, such as stem cell factor (SCF), endothelin-3 (ET-3) and basic fibroblast growth factor (bFGF) (12-16). During development, non-pigmented melanocyte precursors proliferate in the dermis, migrate into the epidermis, and subsequently invade the hair follicle. In the trunk skin of adult mice, the anatomical location of melanocytes is restricted to the hair follicle and therefore, is tightly linked to the regeneration cycle of hair follicles $(17,18)$. There is accumulating evidence that some human cancers after acquisition of an oncogenetic mutation switch their genetic profile to an embryonic stage (2). Therefore, it is of high interest to identify the genetic programs active in embryonic neural crest stem cells and melanoblasts, adult melanocytic cells, and melanoma cells and to investigate growth factor responsiveness of these cell populations.

In this chapter, we provide a protocol for the differentiation of melanocytes from embryonic multipotent neural crest stem cells. The first step of this protocol consists in the isolation of neural tubes from mouse embryos, followed by plating of the neural tubes onto a fibronectin substrate with subsequent emigration of neural crest stem cells (20 hours). This results in relatively pure population of embryonic neural crest cells (Fig. 1). The second step includes the differentiation of neural crest stem cells into melanocytes by incubation of the explant cultures in a specific melanocyte medium for 10 days in vitro (Fig. 1). After 10 days of culture, the majority of neural crest stem cells acquires a melanocytic fate and turns on pigment synthesis, as evident from pigment appearance in the culture dish (Fig. 2). Pigment-positive cells can be easily visualized by inverted microscope using a bright field filter. At this point, cells can be fixed for immunocytochemical analysis of melanocyte-specific markers (Mitf, Dct, Tyr). It is important to note that the addition of fetal calf serum (FCS) is not sufficient for melanocytic differentiation, as only a cocktail of specific growth factors can drive the differentiation process (Fig.3).

This protocol can be applied for the identification of factors regulating proliferation and differentiation of stem cells and melanoblasts and for the generation of cell sources necessary to establish gene expression signatures of embryonic neural crest stem cells producing melanocytes. Comparison of these data with those obtained from adult melanocytes and melanoma cells helps to identify and characterize molecular mechanisms possibly involved in melanoma initiation and progression (8). 


\section{Materials}

1. Hank's Balanced Salt Solution (HBSS) without phenol red (Cat. No. 14025-092, Invitrogen, Life Technologies), Hank's Balanced Salt Solution (HBSS) wihtout $\mathrm{Ca}^{2+}$ and $\mathrm{Mg}^{2+}$ (Cat. No. 14170-088, Invitrogen, Life Technologies).

2. Phosphate Buffered Saline (PBS) pH 7.4 (1x) (Cat. No. 10010-015, Invitrogen, Life Technologies).

3. Water, Double Processed Tissue Culture Water (Cat. No. W3500, Sigma).

4. Penicillin and Streptomycin (Cat. No. 15140-122, Invitrogen, Life Technologies).

5. Sterile cell culture plastic pipettes individually wrapped $(2,5,10,25$ $\mathrm{ml}$ ).

6. Plasticware: cell culture dish (35 mm x $10 \mathrm{~mm}$ ) (Corning Incorporated, Corning. Cat. No. 430165).

7. Dispase I (neutral protease, grade I), 10x approx. $2 \mathrm{mg}$ (Cat. No. 04 942086 001, Roche).

8. Substrate coating: $0.1 \%$ solution of fibronectin (Cat. No. F1141, Sigma).

9. Syringe Driver Filter Unit, $0.22 \mu \mathrm{m}$ (Cat. No. SLGP033RS, Millex-GP).

10. $50 \mathrm{ml}$ of neural crest medium is composed of $47.1 \mathrm{ml}$ of $\mathrm{L}_{15 \mathrm{CO}_{2}, 50}$ $\mathrm{mg}$ BSA $(1 \mathrm{mg} / \mathrm{ml}), 2 \mathrm{ml}$ of $1: 1: 2,50 \mu \mathrm{l}$ insulin $(5 \mu \mathrm{g} / \mathrm{ml}), 100 \mu \mathrm{l}$ putrescine $(16 \mu \mathrm{g} / \mathrm{ml}), 10 \mu \mathrm{l}$ progesterone $(20 \mathrm{nM}), 15 \mu \mathrm{l}$ selenious acid (30 nM), $0.5 \mu \mathrm{l}$ dexamethasone, $143 \mu \mathrm{l}$ glycerol, $50 \mu \mathrm{l}$ vitamin E (5 $\mu \mathrm{g} / \mathrm{ml}), 500 \mu \mathrm{l} \mathrm{Mix} \mathrm{7,} 20 \mu \mathrm{l} \mathrm{bFGF}(10 \mathrm{ng} / \mathrm{ml})$ and $100 \mu \mathrm{l}$ transferrin $(100 \mu \mathrm{g} / \mathrm{ml})$.

11. To prepare $\mathrm{L}^{15 \mathrm{CO}_{2}}$, mix $3.675 \mathrm{~g}$ of Leibovitz's L-15 powder (Cat. No. 41300-021, Invitrogen, Life Technologies), $0.019 \mathrm{~g}$ imidazole (Cat. No. I-0250, Sigma), $1.6 \mathrm{ml}$ of stable vitamin mix and $288 \mathrm{ml}$ of water. Adjust $\mathrm{pH}$ to 7.4. Separately, mix $0.8 \mathrm{~g}$ sodium bicarbonate (Cat. No. S5761, Sigma), $120 \mu \mathrm{l}$ phenol red, $59 \mathrm{ml}$ of water and apply $\mathrm{CO}_{2}$ until the solution turns yellow. Add sodium bicarbonate solution and repeat $\mathrm{CO}_{2}$ step. Store at $4^{0} \mathrm{C}$.

12. To prepare stable vitamin mix, mix $0.6 \mathrm{~g}$ aspartic acid (Cat. No. A4534, Sigma), 0.6 g L-glutamic acid (Cat. No. G-8415, Sigma), 0.6 g Lproline (Cat. No. P-4655, Sigma), 0.6 g L-cysteine (Cat. No. C-7602, Sigma), 0.2 g p-aminobenzoic acid (Cat. No. 42,976-7, Aldrich), 0.2 g 3aminoproprionic acid (Cat. No. A-9920, Sigma), $80 \mathrm{mg}$ vitamin $\mathrm{B}_{12}$ (Cat. No. V-6629, Sigma), 0.4 g myo-inositol (Cat. No. I-7508, Sigma), $0.4 \mathrm{~g}$ choline chloride (Cat. No. C-7527, Sigma), $1 \mathrm{~g}$ fumaric acid (Cat. No. F-8509, Sigma), $16 \mathrm{mg}$ coenzyme A (Cat. No. C-4282, Sigma) (solution 1). Separately, dissolve $0.4 \mathrm{mg}$ D-biotin (Cat. No. B-4639, Sigma) and $100 \mathrm{mg}$ DL- $\alpha$-lipoic acid (Cat. No. T-1395, Sigma) in $10 \mathrm{ml}$ of water (solution 2). Add $2 \mathrm{ml}$ of solution 2 to solution 1, mix and prepare $1.5 \mathrm{ml}$ aliquots.

13. To prepare 1:1:2, dissolve 60 g dextrose (Cat. No. G-7021, Sigma) in $160 \mathrm{ml}$ of water (adjust the volume to $200 \mathrm{ml}$ after dextrose is dissolved). Add $100 \mathrm{ml}$ glutamine (Cat. No. G-6392, Sigma) (200 mM) 
and $100 \mathrm{ml}$ of penicillin-streptomycin solution. Prepare $2 \mathrm{ml}$ aliquots and store at $-20^{\circ} \mathrm{C}$.

14. To prepare Mix7, dissolve 630 mg DL- $ß$-hydroxybutyrate (Cat. No. H6501, Sigma) in $10 \mathrm{ml}$ water. Dissolve cobalt chloride (Cat. No. C-8661, Sigma) in water $(10 \mathrm{mg} / \mathrm{ml})$ and subsequently prepare $25 \mu \mathrm{g} / \mathrm{ml}$ solution by diluting it in $\mathrm{L}_{15 \mathrm{CO}_{2}}$. Dissolve biotin in DMSO $(10 \mathrm{mg} / \mathrm{ml})$ and dilute it in $\mathrm{L}^{15 \mathrm{CO}_{2}}(1 \mathrm{mg} / \mathrm{ml})$. Dissolve oleic acid (Cat. No. 0-7501, Sigma) in water $(2.8 \mathrm{mg} / \mathrm{ml})$ and subsequently in $\mathrm{L}^{15 \mathrm{CO}_{2}}$ up to 10 $\mu \mathrm{g} / \mathrm{ml}$. Dissolve prostaglandin (Cat. No. P-5515, Sigma) in 95\% ethanol to obtain $1 \mathrm{mg} / \mathrm{ml}$ solution and dilute in $\mathrm{L}_{15 \mathrm{CO}_{2}}(10 \mu \mathrm{g} / \mathrm{ml})$. Dissolve 3,3',5-triodo L-threonine (Cat. No. T-6397, Sigma) in DMSO (up to $10 \mathrm{mg} / \mathrm{ml}$ ) and dilute it further in $\mathrm{L}^{15 \mathrm{CO}_{2}}$ to $67.5 \mu \mathrm{g} / \mathrm{ml}$. Mix 5 $\mathrm{ml}$ of each solution with $15 \mathrm{ml}$ of $\mathrm{L}^{15 \mathrm{CO}_{2}}$, prepare $550 \mu \mathrm{l}$ aliquots and store at $-20^{\circ} \mathrm{C}$.

15. Melanocyte differentiation media is composed of DMEM/F12 GlutaMAX Dulbeccos's Modified Eagle Medium (Cat. No. 31331-028, Gibco by Life Technologies) supplemented with penicillinstreptomycin (P/S), L-Glutamine (L-Gln) 200 mM (Cat. No. 25030-024, Invitrogen, Life Technologies) and $5 \%$ FCS. To prepare $160 \mu \mathrm{M}$ stock solution of TPA, dilute TPA (12-O-tetradecanoyl phorbol-13-acetate, Cat. No. P1585, Sigma) into ethanol and store it at $-20^{\circ} \mathrm{C}$ (final concentration is $160 \mathrm{nM}$ ). mSCF (stem cell factor/mast cell growth factor, mouse, recombinant, Cat. No. 250-03, Peprotech). Prepare $50 \mu \mathrm{g} / \mathrm{ml}$ stock solution by dissolving in PBS (final concentration is 50 ng/ml). ET-3 (endothelin 3, human, Cat. No. E9137, Sigma). Prepare $50 \mu \mathrm{M}$ stock solution by dissolving in PBS (final concentration is 100 nM). bFGF (fibroblast growth factor-basic, human, recombinant, Cat. No. 100-18B, PeproTech). Prepare $25 \mu \mathrm{g} / \mathrm{ml}$ stock solution by dissolving in PBS (final concentration is $25 \mathrm{ng} / \mathrm{ml}$ ). $\alpha$-MSH $(\alpha-$ melanocyte stimulating hormone, synthetic, Cat. No. M4135, Sigma). Prepare $100 \mu \mathrm{g} / \mathrm{ml}$ stock solution by dissolving in water (final concentration is $100 \mathrm{ng} / \mathrm{ml}$ ). Dex (dexamethasone, Cat. No. D4902, Sigma). Prepare $1 \mathrm{mM}$ stock by dissolving in $95 \%$ ethanol (final concentration is $1 \mathrm{nM}$ ).

\section{Methods}

1. Isolate E9.5 embryos from the uterus of time-mated females and place them into $10-\mathrm{cm}$ petri dish with sterile HBSS without phenol red. From this step onwards, embryos and tissue should be stored on ice.

2. Dissect the trunks and place them into a new $3.5 \mathrm{~cm}$ dish containing HBSS without phenol red. Prepare a mixture for enzymatic digestion. For this, dissolve 1 vial of Dispase I into $12 \mathrm{ml}$ of HBSS (without $\mathrm{Ca}^{2+}$ and $\mathrm{Mg}^{2+}$ ). Add $12 \mathrm{ml}$ of dissolved Dispase I 
into 6 well plate ( $2 \mathrm{ml}$ per each well) and transfer the trunks into this mixture for $5 \mathrm{~min}$ at $4^{\circ} \mathrm{C}$ using a Pasteur pipette.

3. In order to isolate neural tubes, carefully triturate the trunks using a Pasteur pipette. After the trituration step, transfer neural tubes into DMEM media supplemented with 10\% FCS to stop the enzymatic digestion step (at this step one can collect all neural tubes again in one $3.5 \mathrm{~cm}$ petri dish).

4. Prepare $3.5 \mathrm{~cm}$ petri dishes for culturing: coat every $3.5 \mathrm{~cm}$ (Corning petri dish) with fibronectin. Add $1 \mathrm{ml}$ of culture media into $3.5 \mathrm{~cm}$ dishes and place tissue culture dishes into the cell culture incubator.

5. Plating of neural tubes: remove media (by leaving around $200 \mu \mathrm{l}$ ) and place carefully neural tube on the bottom of $3.5 \mathrm{~cm}$ plate (we usually plate 2-3 neural tubes per dish). This step has to be done under the dissecting microscope. Try to avoid producing air bubbles as in this case, neural tubes will not attach. Use $20 \mu \mathrm{l}$ Gilson pipette at this step.

6. After 30 minutes of incubation at $37^{0} \mathrm{C}$ in the $\mathrm{CO}_{2}$ incubator, carefully add the remaining media (removed at step 5 and collected into $50 \mathrm{ml}$ tube) by controlling whether neural tubes are still attached.

7. Incubate the neural crest explants at $37^{\circ} \mathrm{C}$ with $5 \%$ humidified $\mathrm{CO}_{2}$ for 20 hours to allow neural crest cells to emigrate from neural tube onto the plastic dish. Examine neural crest explants by phase microscopy.

8. To initiate melanocyte differentiation, remove neural crest medium and add melanocyte medium (see components above).

9. Medium should be changed every 3 days until appearance of visible pigmented cells.

\section{Notes}

1. The developmental stage of the embryos is very important (if you start the preparation using embryos older than E9.5, the yield of neural crest stem cells might be very low).

2. Be careful when coating $3.5 \mathrm{~cm}$ dishes with fibronectin solution, do not let it dry.

3. As the trituration step is critical, it is recommended to incubate the trunks at $4^{0} \mathrm{C}$ exactly for 5 minutes and immediately proceed with the trituration.

4. For the melanocytic differentiation step, add the melanocyte medium as soon as neural crest stem cells have emigrated. Delay might result in the acquisition of non-melanocytic fates due to spontaneous differentiation. 
References:

1. Palmer, N. P., Schmid, P. R., Berger, B., and Kohane, I. S. (2012) A gene expression profile of stem cell pliripotentiality and differentiation is conserved across diverse solid and hematopoietic cancers, Genome Biol 13, R71.

2. Youssef, K. K., Lapouge, G., Bouvree, K., Rorive, S., Brohee, S., Appelstein, O., Larsimont, J. C., Sukumaran, V., Van de Sande, B., Pucci, D., Dekoninck, S., Berthe, J. V., Aerts, S., Salmon, I., Del Marmol, V., and Blanpain, C. (2012) Adult interfollicular tumour-initiating cells are reprogrammed into an embryonic hair follicle progenitor-like fate during basal cell carcinoma initiation, Nat Cell Biol 14, 1282-94.

3. Yu, L., Harms, P. W., Pouryazdanparast, P., Kim, D. S., Ma, L., and Fullen, D. R. (2010) Expression of the embryonic morphogen Nodal in cutaneous melanocytic lesions, Mod Pathol 23, 1209-14.

4. Strizzi, L., Hardy, K. M., Kirsammer, G. T., Gerami, P., and Hendrix, M. J. (2011) Embryonic signaling in melanoma: potential for diagnosis and therapy, Lab Invest 91, 819-24.

5. Shakhova, O., and Sommer, L. (2008-2010) Neural crest-derived stem cells, Stem Book, Cambridge (MA): Harvard Stem Cell Institute, May 4.

6. Boiko, A. D., Razorenova, O. V., van de Rijn, M., Swetter, S. M., Johnson, D. L., Ly, D. P., Butler, P. D., Yang, G. P., Joshua, B., Kaplan, M. J., Longaker, M. T., and Weissman, I. L. (2010) Human melanoma-initiating cells express neural crest nerve growth factor receptor CD271, Nature 466, 133-7.

7. Civenni, G., Walter, A., Kobert, N., Mihic-Probst, D., Zipser, M., Belloni, B., Seifert, B., Moch, H., Dummer, R., van den Broek, M., and Sommer, L. (2011) Human CD271-positive melanoma stem cells associated with metastasis establish tumor heterogeneity and long-term growth, Cancer Res 71, 3098-109.

8. Shakhova, O., Zingg, D., Schaefer, S. M., Hari, L., Civenni, G., Blunschi, J., Claudinot, S., Okoniewski, M., Beermann, F., Mihic-Probst, D., Moch, H., Wegner, M., Dummer, R., Barrandon, Y., Cinelli, P., and Sommer, L. (2012) Sox10 promotes the formation and maintenance of giant congenital naevi and melanoma, Nat Cell Biol 14, 882-90.

9. Stemple, D. L., and Anderson, D. J. (1992) Isolation of a stem cell for neurons and glia from the mammalian neural crest, Cell 71, 973-85.

10. Kleber, M., Lee, H. Y., Wurdak, H., Buchstaller, J., Riccomagno, M. M., Ittner, L. M., Suter, U., Epstein, D. J., and Sommer, L. (2005) Neural crest stem cell maintenance by combinatorial Wnt and BMP signaling, J Cell Biol 169, 309-20.

11. Paratore, C., Goerich, D. E., Suter, U., Wegner, M., and Sommer, L. (2001) Survival and glial fate acquisition of neural crest cells are regulated by an interplay between the transcription factor Sox10 and extrinsic combinatorial signaling, Development 128, 3949-61.

12. Langtimm-Sedlak, C. J., Schroeder, B., Saskowski, J. L., Carnahan, J. F., and Sieber-Blum, M. (1996) Multiple actions of stem cell factor in neural crest differentiation in vitro, Dev Biol 174, 345-59. 
13. Sieber-Blum, M. (1998) Growth factor synergism and antagonism in early neural crest development, Biochem Cell Biol 76, 1039-50.

14. Lahav, R., Dupin, E., Lecoin, L., Glavieux, C., Champeval, D., Ziller, C., and Le Douarin, N. M. (1998) Endothelin 3 selectively promotes survival and proliferation of neural crest-derived glial and melanocytic precursors in vitro, Proc Natl Acad Sci U S A 95, 14214-9.

15. Le Douarin, N. M., Creuzet, S., Couly, G., and Dupin, E. (2004) Neural crest cell plasticity and its limits, Development 131, 4637-50.

16. Sommer, L. (2011) Generation of melanocytes from neural crest cells, Pigment Cell Melanoma Res 24, 411-21.

17. Osawa, M. (2008-2009) Melanocyte stem cells, Stem Book, Cambridge (MA): Harvard Stem Cell Institute, June 30.

18. Blanpain, C., and Fuchs, E. (2006) Epidermal stem cells of the skin, Annu Rev Cell Dev Biol 22, 339-73. 
Figure 1. A shematic representation of a protocol of in vitro derivation of melanocytes from embryonic neural crest stem cells. In the first step, a neural tube is isolated from the mouse embryo at the embryonic day 9.5 and plated onto the culture dish, previously coated with fibronectin. After 20 hours of incubation, a population of undifferentated neural crest stem cells emigrate from the neural tube onto fibronectin-coated surface. In the second step of this protocol, neural crest stem cells can be stimulated to acquire melanocytic differentiation by the addition of culture media containing specific growth factors. NT, neural tube. ET-3, endothelin-3. mSCF, mouse stem cell factor. $\alpha-$ $\mathrm{MSH}$, alpha-melanocyte-stimulating hormone. TPA, 12-0-tetradecanoylphorbol13-acetate. Dex, dexamethasone. FGF2, basic fibroblast growth factor.

Figure 2. An example of melanocytes derived from embryonic neural crest stem cells. After 10 days of culture (media has to be refreshed every 2-3 days) in melanocyte media supplemented with specific growth factors, one can observe an increasing number of pigmented cells. These cells can be easily visualized using bright field microscope.

Figure 3. Requirement of specific growth factors for the melanocytic differentation. Only the specific growth factors (ET-3, mSCF, $\alpha-\mathrm{MSH}, \mathrm{TPA}, \mathrm{Dex}$, FGF2) can support the acquisition and survival of the melanocytic differentiation. FCS alone is not sufficient to drive the melanocytic differentation from the embryonic neural crest stem cells. FCS, fetal calf serum. 


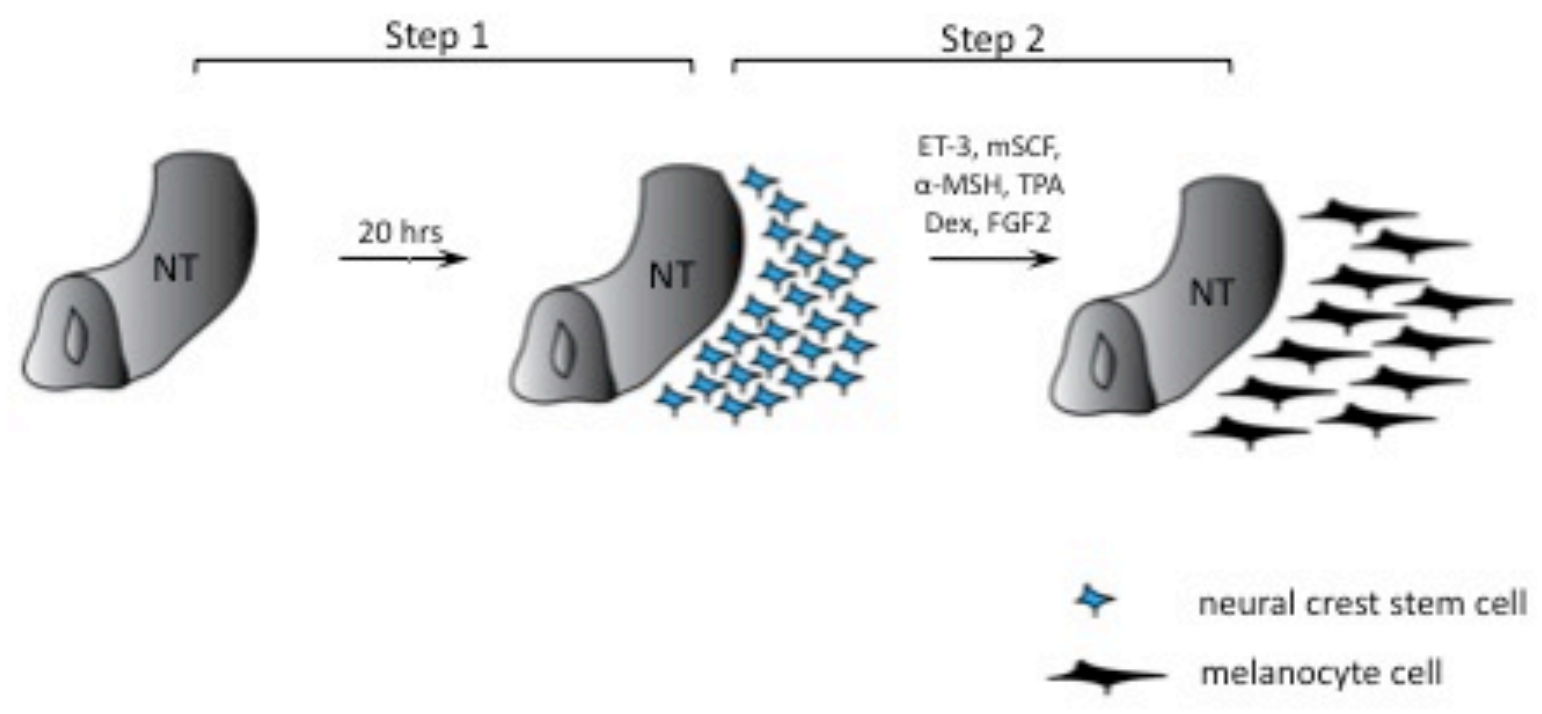

Figure 1. 


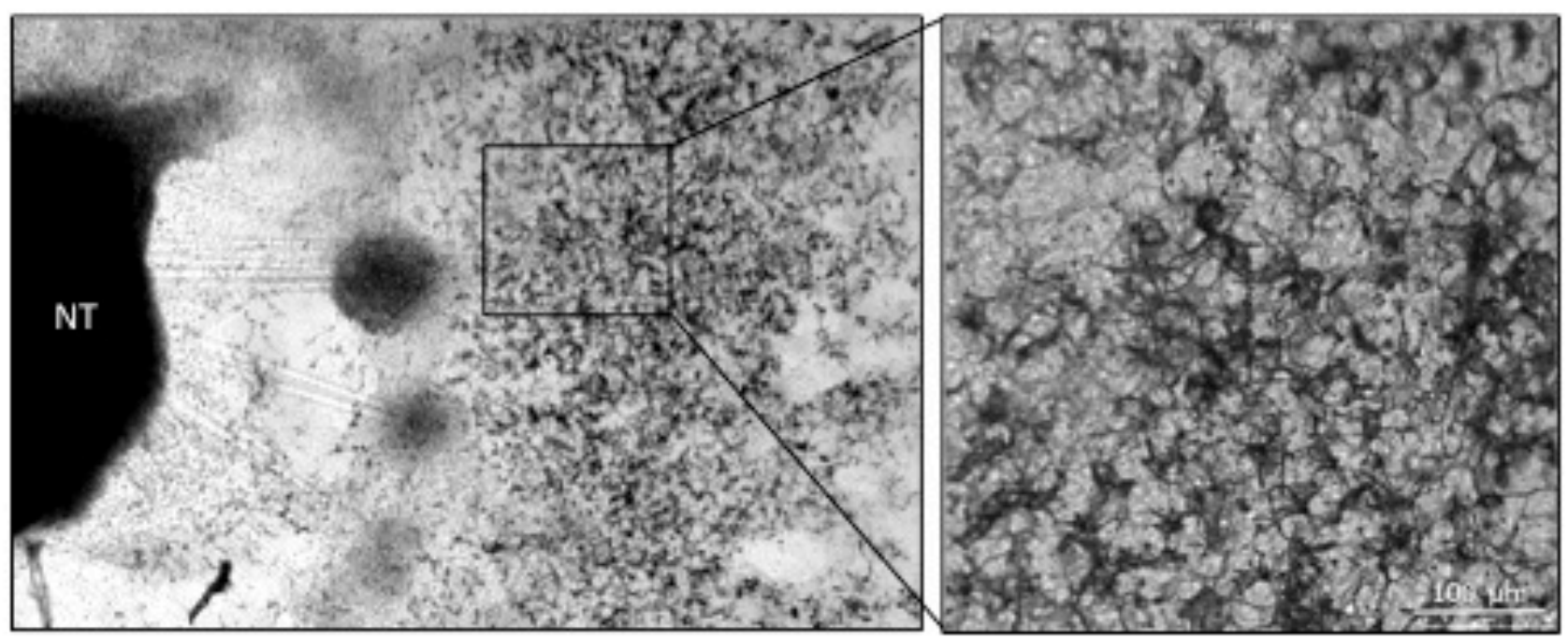

Figure 2. 


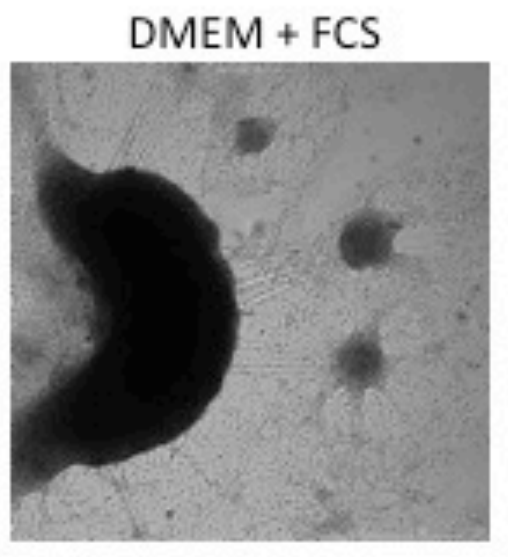

DMEM + FCS + factors
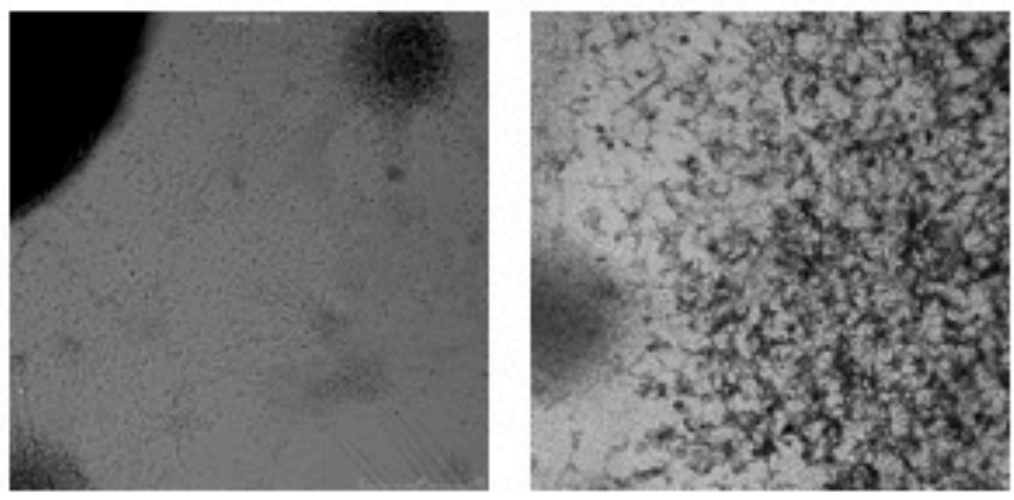

Figure 3 . 